\title{
Transformational leadership: journal club for emergency and intensive care nurse managers
}

\author{
Liderança transformacional: clube de leitura para enfermeiros gerentes de urgência e emergência \\ Liderazgo transformacional: club de lectura para enfermeros gerentes de urgencia y emergência
}

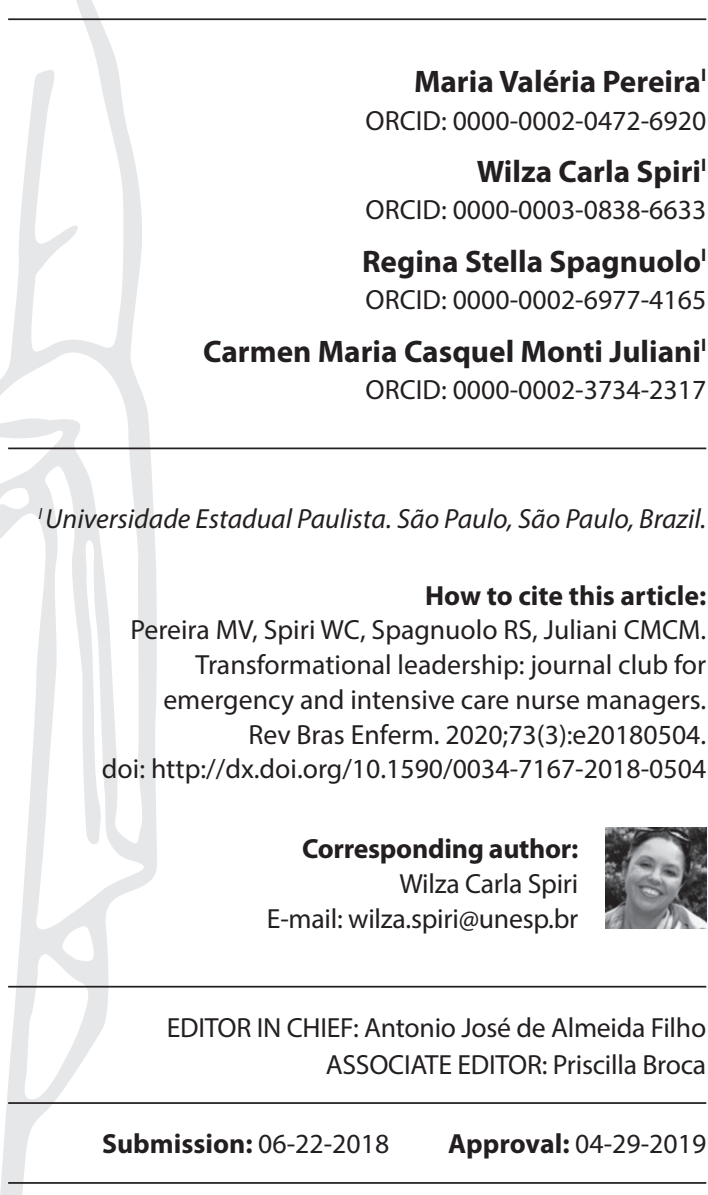

\begin{abstract}
Objectives: to understand the meaning of transformational leadership and develop an educational intervention addressing this theme. Methods: content analysis and action research for the collective construction of an educational intervention addressing management practices and their association with transformational leadership. The setting was the emergency and intensive care network, and nine nurse managers participated in the research. Data was collected from recorded and individualized interviews, and by using the journal club strategy. Results: the unveiled themes were: factors related to the team, to the leadership processes and to the leader. Difficulties in decision-making and planning processes were revealed; the leader needs to work in teams, which in turn should be appropriately sized. The journal club and planning model used provided the praxis of this work. Final Considerations: reflection and training for the development of transformational leadership were fundamental to solidify the decision-making processes involved in the managers' practice.

Descriptors: Leadership; Professional Practice Management; Nurses; Emergencies; Qualitative Research; Nursing.
\end{abstract}

\section{RESUMO}

Objetivos: compreender o significado de liderança transformacional e desenvolver uma intervenção educativa sobre liderança. Métodos: análise de conteúdo e pesquisa-ação para a construção coletiva de uma intervenção educativa sobre a prática gerencial e sua interface com a liderança transformacional. O cenário foi a rede de urgência e emergência e participaram nove enfermeiros gerentes. A coleta de dados foi por meio de entrevistas áudio gravadas e individualizadas e pela estratégia do clube de leitura. Resultados: os temas desvelados foram: fatores relacionados à equipe, aos processos de liderança e ao líder. Revelou-se dificuldades no processo decisório e no planejamento; o líder necessita trabalhar em equipe e com dimensionamento de pessoal adequado. $O$ clube de leitura e a matriz de planejamento utilizada proporcionaram a práxis. Considerações Finais: a reflexão e instrumentalização para o desenvolvimento de liderança transformacional foi fundamental para a prática dos gerentes solidificando o processo decisório no gerenciamento do serviço.

Descritores: Liderança; Gerenciamento da Prática Profissional; Enfermeiros; Emergências; Pesquisa Qualitativa; Enfermagem.

\section{RESUMEN}

Objetivos: identificar el significado del liderazgo transformacional y desarrollar una intervención educativa sobre liderazgo. Métodos: análisis de contenido e investigaciónacción para elaborar colectivamente una intervención educativa sobre la práctica gerencial y su interfaz con el liderazgo transformacional. Se realizó en la red de urgencia y emergencia, y participaron nueve enfermeros gerentes. La recolección de datos se hizo mediante entrevistas grabadas en audio individualmente y también mediante la estrategia del club de lectura. Resultados: los temas desvelados fueron los factores relacionados al equipo, a los procesos de liderazgo y al líder. Se revelaron dificultades en el proceso decisorio y en la planificación; el líder necesita trabajar en equipo y con el tamaño del personal adecuado. El club de lectura y la matriz de planificación utilizada proporcionaron la praxis. Consideraciones Finales: la reflexión e instrumentalización para desarrollar el liderazgo transformacional fue fundamental en la práctica de los gerentes, lo que fortalece el proceso decisorio en la gestión del servicio. Descriptores: Liderazgo; Gestión de la Práctica Profesional; Enfermeros; Urgencias Médicas; Investigación Cualitativa; Enfermería. 


\section{INTRODUCTION}

In the context of health systems, as they work in different units, nurses perform a set of activities with varying natures. They are entrusted with the assistance and management of care and of the health care unit. This process includes the development of administrative, health care-related, educational and research activities. Thus, leadership, implied in all these activities, is one of the fundamental strategies for the praxis of nurses.

Leadership has been studied in a variety of disciplines and fields, such as psychology, education, management of health systems and, more recently, in nursing. Within these areas, the concepts of leadership include four key elements in their definitions: leadership is a process, it involves influence, it occurs within a context or a group and it implies in the achievement of goals that reflect a common vision ${ }^{(1)}$.

One of the styles that is related to the development of leadership skills and of the skills of the team itself is transformational leadership (TL). It considers a relationship based on trust, which positively influences both the leader and those led, making the organizational goals and objectives a collective purpose. Transformational leaders know the organization's culture and values, stimulate creativity and innovation, support and promote changes and fundamentally seek to cultivate these values and behaviors in their functional body ${ }^{(2)}$.

Transformational leaders are passionate about an ideal, inspiring and motivating those led by them to transcend their own interests for the good of the organization, modifying their ways of thinking and helping them look at issues from different perspectives. They are able to encourage others to give their best for the achievement of the team's goals. They offer individualized consideration and intellectual promotion to their team members, in addition to having charisma ${ }^{(3)}$.

$\mathrm{TL}$ is a form of social influence that has wide applicability in nursing, as it is a style of leadership that inspires and empowers followers to achieve extraordinary results by transcending and aligning the objectives and goals of followers and groups, being a distinct model that provides support to organizations in the pursuit of results ${ }^{(4)}$.

The emergency and intensive care sector is a scenario where the participation of nurses is essential. The nurses in this sector need to adopt participatory leadership styles, share and/or delegate duties, with the main skills needed for the management of care being communication, interpersonal skills, decision making and technical competence ${ }^{(5)}$.

Among the different areas of action of nurses, in emergency and intensive care, setting of this research, their activities include participation in the ongoing education process, both as facilitators of this process and as apprentices, because emergencies and intensive care require a comprehensive and up-do-date set of skills. Thus, strategies that facilitate the exchange of knowledge are essential.

The journal club strategy presupposes the use of social learning activities to integrate new knowledge in a context of experiences that have already been had. This strategy is described in the literature as beneficial to the development of nurses for improving their ability of evaluation, promoting the use of clinical evidence in practice and creating a permanent forum for discussion and education ${ }^{(6)}$.
Considering the relevance of this topic, the research was developed based on the following questions:

Are the nurse managers of the emergency and intensive care systems developing themselves in TL? How to promote the development of this network's managers for the effective exercise of leadership? Are these managers familiar with TL?

\section{OBJECTIVES}

To understand the meaning of TL from the perspective of nursing managers in an emergency and intensive care network, and use the journal club strategy to develop a learning environment for the exercise of TL.

\section{METHODS}

\section{Ethical aspects}

This study was developed according to resolution No. 446 of the National Health Council, of 12 December, 2012, having been approved by the Research Ethics Committee of Anhanguera Educacional.

\section{Methodological framework}

A qualitative approach anchored in two steps was adopted, based on the scope and reach of the objectives proposed.

In the first step, content analysis was conducted, because considering the universe of qualitative research, the choice of method and data analysis techniques requires a multifaceted perspective on the data collected due to the plurality of meanings inherent to its polysemic character. This method comprises a set of research techniques, the purpose of which is the pursuit of the meaning or meanings of a document ${ }^{(7)}$.

Studies in the fields of nursing and education have been applying data analysis to a variety of data with different levels of interpretation and multiple meanings. The term "condensation" is described as the process of reducing reports, while preserving their essence. The theme, expressed by the text's latent content (interpretative level), may comprise several categories and can also be divided into sub-themes ${ }^{(8)}$.

In the second step, action research was adopted for allowing the interaction between researchers and participants, enabling the transformation of practice with active participation in the educational action ${ }^{(9)}$. In this study, strategic action research was used $^{(10)}$, i.e., when the transformation is planned in advance. The journal club strategy was adopted for this action ${ }^{(6)}$, as it presupposes the use of social learning activities to integrate new knowledge in a context of experiences that have already been had. The data gathered in this step were also analyzed according to the content analysis technique ${ }^{(8)}$.

\section{Study setting and period}

The study's setting was the emergency and intensive care network of a municipality in the state of São Paulo, in the period from January 2015 to January 2016. 


\section{Study sample}

A convenience sample was used. The lead researcher discussed the design and objectives of the research with the participants, obtaining their informed consent and ensuring the confidentiality and protection of the data.

There were 10 nursing managers in the recruitment period, all of whom were invited, and nine accepted to participate in the research. All nine participated in step one, and seven participated in step two.

\section{Data collection and analysis}

In step 1, the data was collected from individual interviews with open-ended questions. The interview plan consisted in checking the participants' availability, ensuring that the interviews' environment was adequate and safe, and asking permission for the interview to be recorded in audio. The guiding questions were: "Please tell me your experience with leadership." and "What does transformational leadership mean to you?"

The testimonials were individually analyzed and identified by the letter A, corresponding to the interviewee's condition as nurse manager, followed by the number of the interview. The data were analyzed according to the content analysis technique ${ }^{(8)}$. After the individual analyses, a global framework was built with the themes that emerged from the reports, which were categorized into the themes and sub-themes validated by the participants at the time of the educational intervention.

In step 2, the journal club was held, considering the establishment of a learning environment from the articulation with the emergency and intensive care network's coordinating body, which provided the location for the meetings and encouraged the managers' participation.

The participants and the lead researcher agreed on the number and period of the meetings, and the topics of discussion were planned by researcher with the participants' consent.

Three meetings were held. In the first one, group activities were performed for the participants to introduce themselves, having also been used to understand their expectations, explain the purpose of the study, establish the bond of trust between participants and researchers, plan the meetings (date, duration, strategies and themes), read the text about $\mathrm{TL}$, develop the case study on practical reflections about leadership, and evaluate the meeting.

In the second meeting, the SWOT matrix was presented as a tool to be used, with the discussion of its use and applicability in managerial practice; also, a text about leadership in emergency and intensive care was read, and the meeting was evaluated.

The third and final meeting involved the reflection about the result of the SWOT matrix's development in the context of practice, as well as the evaluation of the response to the meetings, with the use of an instrument constructed for this purpose.

All meetings were preceded by a snack to promote the participants' relaxation.

The data were analyzed while considering the diagram proposed for the action research: planning, development, description and evaluation of the educational process, and discussed according to the theme: leadership and management.

\section{RESULTS}

The participants were all female, aged 38 years old on average, having been in the position of managers from three to 20 years.

\section{Step 1 - Analysis of the interviews}

In step 1, the nurses characterized TL according to aspects involving the team, the processes of leadership and the role of the leader. Thus, the themes unveiled were: factors related to the team, factors related to the leadership processes, and factors related to the role of the leader. Figure 1 represents these themes.

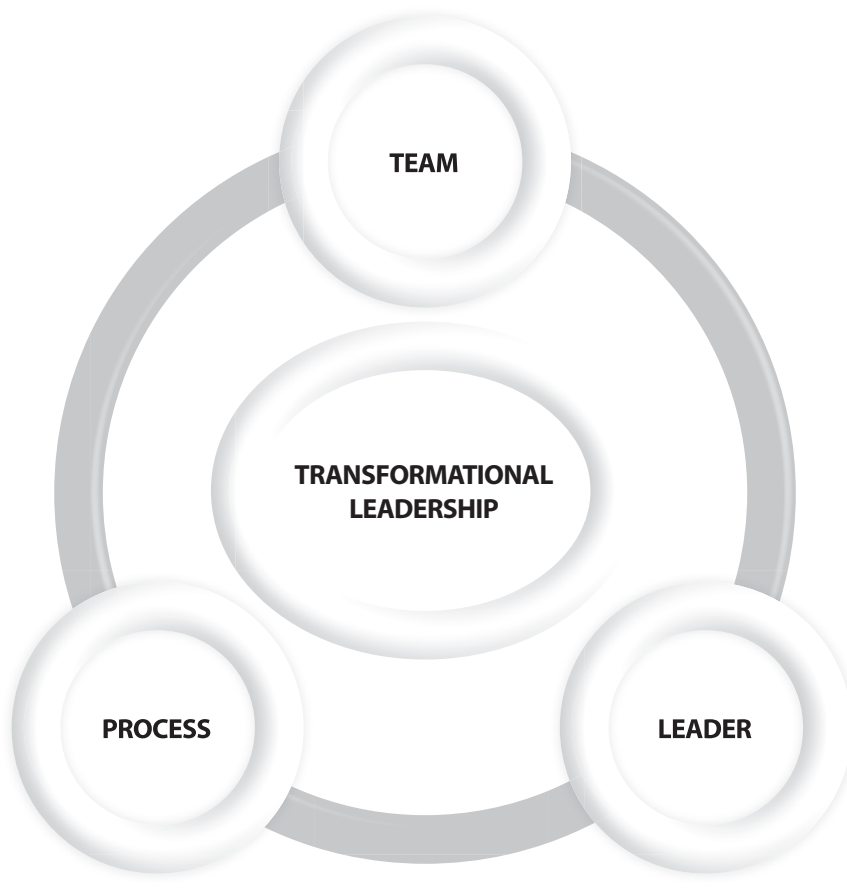

Figure 1 - Themes unveiled

\section{Team-related factors}

This theme covers the sub-themes: TL and team training and team empowerment. These sub-themes revealed that it is necessary that the nurse considers the holism, respects the individualities, recognizes and promotes the skills, capabilities and potential of each team member. It is important that, during the work process, the nurse offers participation opportunities, encourages a common language and shares and searches for solutions to problems, always trying to hear the team. They say in the reports:

\section{We all need to speak the same language, the team needs to be on the same page. (A1) \\ Us nurses need to take the lead and pull the team close to us, I've always worked alongside them. (A4)}

In the subtheme that relates TL and the team's training, it was emphasized that nurses try to use their leadership to reconcile the organizational objectives with those of nursing, seeking the improvement of professional practice and the dissemination of adequate care practices. 
My experience as a leader is training them, trying to motivate them to work so that this always happens. (A1)

The team empowerment subtheme made it possible to articulate the role of TL in the nurses' daily work routine. From the perspective of the participants, team empowerment is related to autonomy and to the provision of safety through knowledge, and thus, to categorical decision making so as to standardize the conducts and offer the team a direction for the development of their technical skills.

Autonomy shows that the group supports you. I think it's important that they find a reference in you. (A4)

\section{Factors related to the leadership process}

This theme revealed the sub-themes: (mis)understanding of the concept of TL; TL and the perception of the concept of leadership; TL and the development of leadership; TL and the challenges of leadership; and TL and the strengths of leadership.

From the perspective of the participants, these sub-themes relate to the process of leadership and to the ways of exercising it, as well as to the concept assigned to TL.

Thus, the subtheme pertaining to the (mis)understanding of the concept of TL showed that the premises of TL are identified and perceived by the nurses as important, although not yet fully present in their everyday life. They stressed the importance of developing the practice of leadership and the necessary skills for its exercise. However, they confuse knowledge, routines and techniques with leadership, and express difficulties leading the work of their collaborators.

Transformational leadership... look, I don't know that much about it, but I believe the transformational leader is the one who transforms the environment somehow, because he has the necessary knowledge and the will to modify it. He does not simply come and fulfill his role as manager. Ibelieve that's what it is, that it brings a new proposal. (A9)

From its name, I understand that $T L$ is something that ensures the participation of all members in that team, so that the leader is not the only one who knows everything, who has control over everything, who is the only one to offer guidance. (A7)

The subtheme pertaining to TL and the perception of the concept of leadership emphasized that each leader has his/her own leadership style, and that determining which style is more appropriate is controversial, since it seems that everything varies depending on the situation.

The subtheme pertaining to TL and the development of leadership revealed the importance of training and perspective.

$\mathrm{He}$ [the leader] is not born ready. I think he evolves and grows with time, but some of this growth also relates to the workenvironment. (A8)

The subtheme pertaining to TL and the challenges of leadership emphasized that the pressure on leaders increases with the need to understand the roles and responsibilities associated with their function. The main challenges relate to the proper sizing of the nursing staff, as there is a shortage of workers; to the management of the existing conflicts between the nursing staff and the multidisciplinary team; to the public management model that prevents effective evaluations and decision making on the part of managers; to interpersonal relationships; to the devaluation of the professionals caused by unequal wages; to feelings of impotence in the decision-making process, and to stress in the work context.

These challenges engender physical and emotional damages and demotivation. They say in the reports:

How to manage a small staff while offering 24-hour services to the amount of patients we see each day, with such a low number of employees available? (A3)

The greatest difficulty is the financial devaluation of nursing professionals, which is very unfair. Here we subject ourselves to emotional and physical wear, it's very difficult, you deal with death, with families, you have to deal with them every day. (A6)

The subtheme pertaining to TL and the strengths of leadership showed that being empowered and empowering the team are fundamental aspects for management and training, in the pursuit of continuous improvement and appropriation of consistent knowledge. The statement below confirms this:

I think training is the only positive aspect of being a leader, it ensures an enormous differential. (A8)

\section{Factors related to the role of the leader}

The sub-themes that emerged were: attitudes of the leader and coordination of the team's work.

The participants reported that it is essential that the leader develops actions that promote respect between the leader and the team, between team members and between the team and the users; they also believe that the role of the leader is coordinating and managing the team's work, negotiating with the team members and developing their collaboration; evaluating the workers; guiding the work process; stimulating the team to perform enjoyable activities that strengthen the bond between members; encouraging communication and dialogue; offering positive feedback and showing appreciation for the work performed; promoting the exchange of knowledge and experiences and establishing a partnership with the team. They say in the reports:

Inotice a lot of respect from the team when the nurse has a leading position, of guiding the team in what needs to be done. (A2)

Laying low before others, talking to them as coworkers. (A6)

I thank them and then say: "that was a difficult shift, but you guys killed it". (A5)

Always with a lot of respect and dialogue, which is something I've always worked with and that I appreciate [...] in leadership, respect is fundamental. (A2)

\section{Step 2 - Journal club}

To promote the development of the managers for the exercise of leadership, journal club meetings were held, during which managerial practices and their interface with TL were discussed. 
This step of the research consisted in the collective construction of an intervention associated with the leadership process to be developed in the reality of the participants.

The first meeting began with the introduction of the seven participants, followed by the presentation of the study's objectives and purpose of the meetings by the researcher, which resulted in the validation of the themes and sub-themes that emerged during the individual interviews, because all participants recognized themselves in the results presented.

Then, a presentation using the "Who am I?" strategy was performed, during which the participants shared ten characteristics that defined them with those present. The main characteristics described were: shyness, determination, creativity, optimism, solidarity, stubbornness, organization, responsibility, flexibility and love of learning.

Subsequently, the participants were asked to manifest their expectations by writing them on a piece of paper shaped like a hand, with the goal of understanding the contributions they could offer and what were their expectations in relation to the intervention process. During this activity, the participants also talked about the inconveniences of everyday life: lack of time; work overload; shortage of material resources; lack of substitutes to cover for them when they are not in the unit; difficulties with the demand for service; shortage of personnel; difficulties in the relationship with users and families, underlined by their disrespect towards the team, leading to the professionals' physical and psychological exhaustion.

The presentation followed no strict guidelines and all participants were willing to talk about their expectations, contributions and annoyances, demonstrating their knowledge and experience in relation to the work developed at the unit. Their knowledge of and willingness to work in the emergency and intensive care service was constantly highlighted by the group, despite all structural and behavioral difficulties. It was also noted that the participants felt confident and comfortable enough to express themselves.

Their expectations for the meetings were: development of tools for the exercise of leadership; improvement in the quality in work; development of praxis; learning of new concepts; exchange of experiences; clarification of doubts; expansion of knowledge; strengthening of bonds of friendship and promotion of a positive working environment; possibility of reflection and discussion of work-related issues; establishment of partnerships and cooperation. They also mentioned their willingness to learn.

After the presentation, a text about a motivating case involving leadership was collectively read and discussed by the group. Based on this case, an exercise for the evaluation of skills was conducted, containing the following items: the skills needed to strategically influence people; the organization, its vision and future; the construction of credibility to obtain support from all levels; the importance of the internal and external policy; the collective effort to deal with the increasing demands; space and opportunities for the leadership of third parties; strategies, using one's "head" and one's "heart"; discussion of sensitive issues, including relationships and talents to enhance the effectiveness of the organization.

There was an extensive discussion about the case, and the participants considered that the leader is the team's "safe haven" and reference. They also said that communication is essential for the leadership process.
Subsequently, a text about TL in nursing ${ }^{(11)}$ was given to the participants, to be read and discussed in the next meeting.

An evaluation was performed at the end of the meeting, using the one-word strategy. The words chosen by the participants were: productive, interesting, knowledge, reflective and stimulating. This made it possible to describe the meeting as a supportive space for reflection.

In the second meeting, the participants were welcomed and asked about the reading of the text given to them in the previous meeting, and one of them said:

We don't fully understand the meaning of $T L$, but all we have some characteristic of it. (A7)

They stressed that it is vital to seek knowledge to apply it in practice, and that, based on the text discussed, TL makes collective work and the development of fairness criteria in a work context possible. They revealed the difficulties in making fair decisions and developing strategies to achieve the goals proposed by the organization.

After the discussion and validation of the text, the SWOT matrix ${ }^{(12)}$ was presented to them by the researcher as a planning tool, because it supports the analysis of the environment, identifying strengths, weaknesses, opportunities and threats.

The participants committed themselves to applying the SWOT matrix together with their team for discussing it in the next meeting, and an article ${ }^{(13)}$ about nursing leadership in the context of emergency and intensive care services was given to them, to be read and discussed also in the next meeting.

In the third and last meeting, the researcher reviewed themes and activities that had already been discussed in previous meetings, and reaffirmed the proposals for the day: discussion of the article about leadership in the context of emergency and intensive care services, presentation of the SWOT matrix and evaluation of the meetings.

The participants reported that the reading of the article was very pertinent because it talked about a context that was similar to theirs, and that the literature review presented is relevant to practice. Leadership in this scenario assumes a fundamental role, because it is from it that the synchrony of teamwork, good quality of service, and reduction in medical and nursing care errors are obtained, generating better results for the patient.

It was also expressed by the participants that the graduate courses in nursing do not properly prepare students for the exercise of leadership, and that nurses do not typically pursuit development in this area. It was explained that the decision-making process in emergency and intensive care units needs to be agile, and thus, leaders need to always be able to make the best decision. They said that the leader must be able to work alongside the team.

Subsequently, the strengths, weaknesses, opportunities and threats of each unit were presented. Some nurses/managers collected these data along with their team and others did it by themselves. The researcher used this opportunity to stress the need for the involvement of the team so that $T L$ is actually developed and put into practice, because the team's participation is fundamental for the development of proposals and construction of new projects, as well as crucial so that improvement processes are solidified and executed. It was considered that the team has great potential for the construction of new projects, and that 
the instrument presented can support the development of the organization's skills and problem-solving strategies.

After the presentation, the researcher concluded the meetings, clarifying that it was not her intention to exhaust the subject, because it raised awareness in relation to the theme of leadership, and suggested, according to the participants' own demand, the creation of spaces for the exchange of experiences and reading of scientific articles, with the purpose of strengthening their actions.

An evaluation proposal was given to the participants, suggesting two types of evaluations, which were accepted and validated by the group. The first evaluation included four scores, the first being great, the second good, the third regular and the fourth bad. The scores were related to the meetings' objectives, importance to professional performance, importance to education, contents, methodology, group relationships, knowledge of the researchers, motivation of the researchers, possibility of resuming the meetings, and dedication of the participant.

All scores were great or good.

The second evaluation had three open-ended questions: I did not expect it but it happened; I was a little disappointed with ...; If I were to talk to a colleague about this educational intervention, I would say that...

The participants' answers were: "I did not expect" that the research could assist in practice, providing motivation for studying about the subject, being important to the development of leadership, enabling gratification and professional growth, supporting open discussions about various topics, helping with difficulties and motivation, being an adequate space for venting and making us feel stimulated to work, "but it happened."

In relation to "I was a little disappointed with", participants expressed having had no time to devote themselves to the proposed activities and to the articles' reading, as well as the distance between theory and practice.

As for how they would talk to others about the educational process, they stressed that the method used can be applied in reality, highlighting the importance of participation in studies with impacts on practice, that the opportunities for personal and professional growth need to be taken advantage of, that it is necessary to believe that things can change and that it is possible to improve the exercise of leadership.

\section{DISCUSSION}

The understanding of the participant is supported by the literature ${ }^{(14)}$, because in the field of health, sharing the planning of strategies and the division of tasks, cooperating, collaborating and interacting democratically are necessary for the development of teamwork, so as to integrate different actors, knowledge, practices, interests and needs. Teamwork occurs from the need to establish common goals and objectives, with a well-defined work plan, through which each actor may grow individually and as group, and care centered on the user and community involved. For the health care provided to have both quality and efficiency, it is essential to understand the real meaning of being part of a team ${ }^{(14)}$.

The permanent responsibility for the educational process needs to be encouraged and promoted in the professionals' training, for the development of an organizational culture that shares responsibilities between the nursing staff and the institution ${ }^{(15)}$.

It is understood that educational activities are included in all actions in nursing. Therefore, there is a need to promote effective teaching opportunities, based on the awareness of the value of education as a means of growth of nursing professionals, as well as the recognition of their educational function in the development of the work process, because for them, knowledge is a necessary value in everyday life and it is the basis of their actions ${ }^{(16)}$.

In what concerns the empowerment needed for leaders to act autonomously in the work context of nursing, the literature indicates the need for the individual construction of nurses, through which the various individual and collective social subjects and actors become aware that they have the ability and competence to produce, create, manage and transform their own lives, their surroundings, becoming the protagonists of their own stories, with influence over the processes that determine their trajectories $^{(17)}$. Thus, training nurses and defining their responsibilities is the only way for them to gain autonomy in their practice ${ }^{(18)}$.

It was noted in the reports of the participants that, while developing the practice of leadership, in relation to the essential skills for its exercise, knowledge, routines and techniques were confused with leadership, the theme and style of leadership being considered unknown. The existence of difficulties in leading the work of collaborators was also revealed. Addressing the development of work is necessary, seeing as leadership actions arise from the difficulty of the moment, not being clearly structured and in accordance with the demands and difficulties of a leadership knowledge that is necessary, appropriate and focused on the indefiniteness of the employing institution ${ }^{(11)}$.

Leadership is a necessary and required competence of nurses. Health institutions seek professionals who are able to exercise it to achieve effective results. Their apprenticeship begins in higher education and continues permanently. When managing the team, receiving and giving feedback, making decisions, resolving conflicts, among others, nurses develop themselves as leaders ${ }^{(19)}$.

The development of leadership is a strategic and instrumental revitalization which has the goal of providing skills and perspectives for managers to become leaders of their subordinates, in the pursuit of concrete results and the continuous improvement of performance ${ }^{(20)}$.

It is important to rethink the role of leaders in the public sector, since excessive transactional leadership leads to the low involvement of employees. This is confirmed by the performance measure revealing that the team's professional commitment corresponds to the lowest performance index. The analysis identified eight actions required in the management of health care that are carried out by nurses in their everyday life: 1) appropriately sizing the nursing staff; 2) exercising leadership in the workplace; 3 ) planning nursing care actions; 4) educating and empowering the nursing staff; 5) managing the material resources; 6) coordinating the care process; 7 ) performing health care practices and/ or more complex procedures; and 8) assessing the outcomes of the nursing actions ${ }^{(21)}$. Thus, the understanding of the role of the leader revealed by the participants is supported by the literature on this subject.

One strength is related to participatory management, where the inclusion of nurses in the decision-making process, an efficient 
communication system, the promotion of permanent education and the demonstration of ethics in the workplace can lead to greater commitment on the part of these professionals in the care of patients. In addition, organizational culture elements can subsidize nurses when confronting the complexities of care ${ }^{(22)}$.

The strategies developed in the journal club allowed the nurses' familiarization with tools for the development of leadership. The SWOT matrix is based on strategic thinking, facilitating the development of opportunities by offering a clear and objective perspective. It is one of the most common practices of companies and an essential tool for an organization, as it allows the organization to become aware of its strengths and weaknesses in the internal environment, and of its opportunities and threats in the external environment, so that managers may draw up strategies to obtain a competitive edge and improve organizational performance ${ }^{(12)}$.

The participants understood that, in all levels of care, nurses play a key role as members of the intensive care team, whether in the direct care of patients, in the management of their team and workplace or in permanent education, seeing as the work in an emergency unit is dynamic, and the health team involved is what determines the service's functional competence, with doctors and nurses playing imperative roles in this process ${ }^{(23)}$.

The study revealed that the adoption of participatory strategies in nursing allows the workers' recognition of the need to open spaces for the discussion of their practices. The literature confirms this result, because it shows that these spaces provide autonomy, knowledge, creativity, responsibility and commitment ${ }^{(24)}$.

The participants of this research also expressed the importance of spaces for the improvement of their work. The journal club strategy has been referred to in the literature as a formal part of nursing education programs, with activities for the renewal, understanding and application of nursing knowledge in practice, thus contributing to evidence-based practice (EBP). In addition, the journal club strategy offers to nurses essential skills for critically reading what has been produced in the literature and analyzing the potential impact of this production on practice. Nurses who actively participate in this strategy can develop methods that support and develop EBP in the healthcare organization where they are inserted ${ }^{(25)}$.

Considering the emergency and intensive care sector as fundamental to users, a study ${ }^{(26)}$ corroborates the results of this research, as it found that leadership in this sector requires the ability to deal with people with different thoughts, opinions and personality in a participatory and dialogic manner, despite this being a very dynamic and busy service.

\section{Study limitations}

The limitation of the study refers to the small number of participants and to its context being restricted to a specific reality.

\section{Contributions to the field of nursing}

The adoption of strategies that promote the teaching-learning process in the context of professional practice, in particular the management process, are fundamental for their more comprehensive use by nurses. In this sense, the adoption of the journal club strategy and the active participation of all involved are strengths of this study and may contribute to other contexts.

The study also contributed to the advancement of science, in that it revealed factors involved in the development of TL in a dynamic setting with very particular specificities, as is that of emergency and intensive care, unheard of in the context of research in nursing.

\section{FINAL CONSIDERATIONS}

The initial ideas and questions became concrete with the team's participation and, in this way, the initial assumption was validated, the nurse's leadership in the context of emergency and intensive care being influenced by the services' structure and by the challenges of the acquisition of knowledge about leadership.

The development of leadership skills such as involvement, empathy for the team and the ability to influence and act enthusiastically is currently one of the challenges of nursing leaders.

It was found that some of the assumptions of TL were identified by the nurses and highlighted as important, but they are not yet fully present in the professionals' everyday life.

The adoption of the journal club strategy stimulated the team to seek tools of support to the development of their work in research and studies on $\mathrm{TL}$, revealing the need for training, appropriation and empowerment in the exercise of leadership.

The spaces of discussion allowed the participants to reflect on their realities and develop strategies based on their strengths and weaknesses, so as to provide clearer guidance for the resolution of problems alongside their team.

The pursuit of knowledge and tools for the development of TL are necessary in the practice of managers, supporting the decisionmaking processes involved in the management of health care services. Nurses, while leaders, must seek continuous improvement, combining technical-scientific knowledge and leadership skills to meet the organization's expectations as well as those of the team, with more critical, participatory and reflective practices.

\section{REFERENCES}

1. Cummings GG, MacGregor T, Davey M, Lee H, Wong CA, Lo E, et al. Leadership styles and outcome patterns for the nursing workforce and work environment: a systematic review. Int J Nurs Stud. 2010;47(3):363-85. doi: 10.1016/j.ijnurstu.2009.08.006

2. Bork AMT. A liderança transformacional e os modelos de gestão. In: Harada MJCS, organizadora. Gestão em enfermagem: ferramenta para uma prática segura. São Caetano do Sul: Yendis; 2011. p. 145-53.

3. Amestoy SC, Backers VMS, Trindade LL, Canever BP. The scientific production regarding leadership in the context of nursing. Rev Esc Enferm USP. 2012;46(1):219-24. doi: 10.1590/S0080-62342012000100030 
4. Ross EJ, Fitzpatrick JJ, Click ER, Krouse HJ, Clavelle JT. Transformational leadership practices of nurse leaders in professional nursing associations. J Nurs Adm. 2014;44(4):201-6. doi: 10.1097/NNA.0000000000000058

5. Rocha ECA. Atuação da enfermagem e urgências e emergências [Internet]. Brasília: Conteúdo Jurídico; 2012 [cited 2017 Jan 08 ]. Available from: http://www.conteudojuridico.com.br/consulta/Artigos/32928/atuacao-da-enfermagem-em-urgencias-e-emergencias

6. Turkel MC, Reidinger G, Ferket K, Reno K. An essential component of the magnet journey: fostering an environment for evidence-based practice and nursing research. Nurs Adm Q. 2005;29(3):254-62.

7. Campos CJG. Método de análise de conteúdo: ferramenta para a análise de dados qualitativos no campo da saúde. Rev Bras Enferm. 2004;57(5):611-4. doi: 10.1590/S0034-71672004000500019

8. Graneheim UH, Lundman B. Qualitative content analysis in nursing research: concepts, procedures and measures to achieve trustworthiness. Nurse Educ Today. 2004;24(2):105-12. doi: 10.1016/j.nedt.2003.10.001

9. Thiollent M. Metodologia da pesquisa-ação. 15th ed. São Paulo: Cortez; 2007.

10. Franco MAS. Pedagogia da pesquisa-ação. Educ Pesqui. 2005;31(3):483-502. doi: 10.1590/S1517-97022005000300011

11. Strapasson MR, Medeiros CRG. Liderança transformacional na enfermagem. Rev Bras Enferm. 2009;62(2):228-33. doi: 10.1590/ S0034-71672009000200009

12. Souza LPS, Souza AMV, Pereira KG, Figueiredo T, Bretas TCS, Mendes MAF, et al. Swot matrix as a management tool for improving nursing care: case study in a teaching hospital. Gestão Saúde [Internet]. 2013 [cited 2018 Apr 13];4(1):1633-43. Available from: http://periodicos.unb. br/index.php/rgs/article/view/207/196

13. Silva DS, Bernardes A, Gabriel CS, Rocha FLR, Caldana G. A liderança do enfermeiro no contexto dos serviços de urgência e emergência. Rev Eletr Enf. 2014;16(1):211-9. doi: 10.5216/ree.v16i1.19615

14. Navarro ASS, Guimarães RLS, Garanhani ML. Teamwork and its meaning to professionals working in the family health strategy program. Rev Min Enferm. 2013;17(1):61-8. doi: 10.5935/1415-2762.20130006

15. Bezerra ALQ, Queiroz ES, Weber J, Munari DB. O processo de educação continuada na visão de enfermeiros de um hospital universitário. Rev Eletr Enf. 2012;14(3):618-25. doi: 10.5216/ree.v14i3.12771

16. Paschoal AS, Mantovani MF, Meier MJ. The perception of permanent, continuous, in service education for nurses in a school hospital. Rev Esc Enferm USP. 2007;41(3):478-84. doi: 10.1590/S0080-62342007000300019

17. Baquero RVA. Empoderamento: instrumento de emancipação social? Uma discussão conceitual. Rev Debates. 2012;6(1):173-87. doi: $10.22456 / 1982-5269.26722$

18. Domingues TAM, Chaves EC. O conhecimento científico como valor no agir do enfermeiro. Rev Esc Enferm USP. 2005;39(esp):580-8. doi: $10.1590 / \mathrm{S} 0080-62342005000500011$

19. Balsanelli AP, Cunha ICKO. Ideal and real leadership of nurses in intensive care units at private and public hospitals. Cogitare Enferm. 2016;21(1):1-7. doi: 10.5380/ce.v21i4.42129

20. Peduzzi M, Carvalho BG, Mandú ENT, Souza GC, Silva JAM. Trabalho em equipe na perspectiva da gerência de serviços de saúde: instrumentos para a construção da prática interprofissional. Physis. 2011;21(2):629-46. doi: 10.1590/\$0103-73312011000200015

21. Santos JLG, Pestana AL, Guerrero P, Meirelles BSH, Erdmann AL. Nurses' practices in the nursing and health care management: integrative review. Rev Bras Enferm. 2013;66(2):257-63. doi: 10.1590/S0034-71672013000200016

22. Galvão J. Gerencia de serviço de urgência e emergência: fortalezas e fragilidades. Rev Enferm Integr [Internet]. 2013 [cited 2018 Mar 28];6(2):1133-42. Available from: https://www.unilestemg.br/enfermagemintegrada/artigo/v6_2/01-gerencia-de-servicos-de-urgencia-eemergencia-fortalezas-e-fragilidades.pdf

23. Chen R, Sharma SK. Organizational capabilities in emergency incident response: an empirical examination. Proceedings of the 7th MWAIS Conference [Internet]; 2012 May 18-19 [cited 2017 Dec 07]. Atlanta: AIS; 2012. Available from: http://aisel.aisnet.org/mwais2012/8

24. Bertolini LRL, Spiri WC, Juliani CMCM. Perception of the nursing team at a specialized hospital about the work process. Int Arch Med. 2016;9(325):1-10. doi: 10.3823/2196

25. Gardner Jr K, Kanaskie ML, Knehans AC, Salisbury S, Doheny KK, Schirm V. Implementing and sustaining evidence based practice through a Nursing Journal Club. Appl Nurs Res. 2016;31:139-45. doi: 10.1016/j.apnr.2016.02.001

26. Amestoy SC, Lopes RF, Santos BP, Dornelles C, Fuculo Junior PRB, Santos EA. Exercício da liderança do enfermeiro em um serviço de urgência e emergência [Internet]. Rev Elet Gest Saúde. 2016 [cited 2017 Dec 07];7(1):38-51. Available from: https://dialnet.unirioja.es/descarga/ articulo/5555878.pdf 